\title{
Reservoir Processes Related to Exploitation in Los Azufres (México) Geothermal Field Indicated by Geochemical and Production Monitoring Data
}

\author{
Víctor Manuel Arellano1, Rosa María Barragán1", Miguel Ramírez², Siomara López1, \\ Alfonso Aragón', Adriana Paredes1, Emigdio Casimiro3 ${ }^{3}$, Lisette Reyes ${ }^{3}$ \\ ${ }^{1}$ Instituto de Investigaciones Eléctricas, Gerencia de Geotermia, Cuernavaca, México \\ ${ }^{2}$ Comisión Federal de Electricidad, Gerencia de Proyectos Geotermoeléctricos, Morelia, México \\ ${ }^{3}$ Comisión Federal de Electricidad, Residencia Los Azufres, Campamento Agua Fría, México \\ Email: ${ }^{\text {rmb @iie.org.mx }}$
}

Received 14 July 2015; accepted 25 September 2015; published 28 September 2015

Copyright (C) 2015 by authors and Scientific Research Publishing Inc.

This work is licensed under the Creative Commons Attribution International License (CC BY). http://creativecommons.org/licenses/by/4.0/

(c) (i) Open Access

\begin{abstract}
A combined analysis of geochemical and production data of 39 wells of the Los Azufres (Mexico) geothermal field (227.4 MWe) over time was developed to investigate the exploitation-related processes for 2003-2011. In the south zone, important effects of reinjection were observed through $\mathrm{Cl}$ increases in some wells (up to $8000 \mathrm{mg} / \mathrm{kg}$ ) while in wells with significant boiling, Cl has decreased. In most of the north zone wells, the variations in gas data indicated boiling and condensation of a highly gas-depleted brine, which seems to consist of reinjection fluids. It is suggested that this process maintains the production in the zone relatively stable. The main reservoir exploitation-related processes found were: 1) production of reinjection returns; for this, it was possible to distinguish a) wells that produce liquid and steam from injection, and b) wells that produce steam from injection and sometimes condensed steam from injection; 2) boiling: two types of boiling were identified: a) boiling with steam gain, and b) boiling with steam loss. The results indicated that an effective reservoir recharge occurs since very moderate production declining rates were found.
\end{abstract}

\section{Keywords}

Los Azufres Geothermal Field, Well Simulation, Fluid Geochemistry, Well Bottom Conditions, Production Wells

\footnotetext{
${ }^{*}$ Corresponding author.
}

How to cite this paper: Arellano, V.M., et al. (2015) Reservoir Processes Related to Exploitation in Los Azufres (México) Geothermal Field Indicated by Geochemical and Production Monitoring Data. International Journal of Geosciences, 6, 1048-1059. http://dx.doi.org/10.4236/ijg.2015.69083 


\section{Introduction}

The Los Azufres geothermal field is an intensely-fractured, two-phase, volcanic hydrothermal system located in the northern portion of the Mexican Volcanic Belt, in the state of Michoacán, at an average elevation of 2800 m.a.s.l. (Figure 1). At present, the installed capacity of the field is 227.4 MWe [1]. Based on the occurrence of natural manifestations, the field was divided into two zones: north and south, although both zones are supplied by the same deep aquifer. Reservoir engineering and geochemical conceptual models of the Los Azufres system were established [2] [3] which constitute the reference conditions that allow characteristic changes in parameters over time to be related to exploitation. The reservoir's response to exploitation for 1982-2002 was studied based on a systematic analysis of chemical, isotopic, and production data from 20 production wells [4]. The installed capacity of the field was 88 MWe during that time. Subsequently, since 2003, four additional 25 MWe flash plants were brought on line, bringing the total installed capacity to 188 MWe which operated till first months of 2015. At present, (August 2015) the capacity has increased to 227.4 MWe and then higher rates in fluids extraction are required to supply units. In order to support decisions on field polices regarding sustainable exploitation, the objective of this work was to investigate the exploitation-related processes through the analysis of geochemical and production data of 39 wells. The Los Azufres geothermal field is operated by the Comisión Federal de Electricidad (CFE). In Figure 1 the locations of the field and the wells are given. All of the injection wells are located on the west side of the field. Injectors Az-3, 15, 52, and 61 are located in the northern production area, whereas Az-7A and 8 are in the south.

\section{Methodology}

In order to obtain the thermodynamic characteristics of reservoir fluids and to investigate the dominant processes

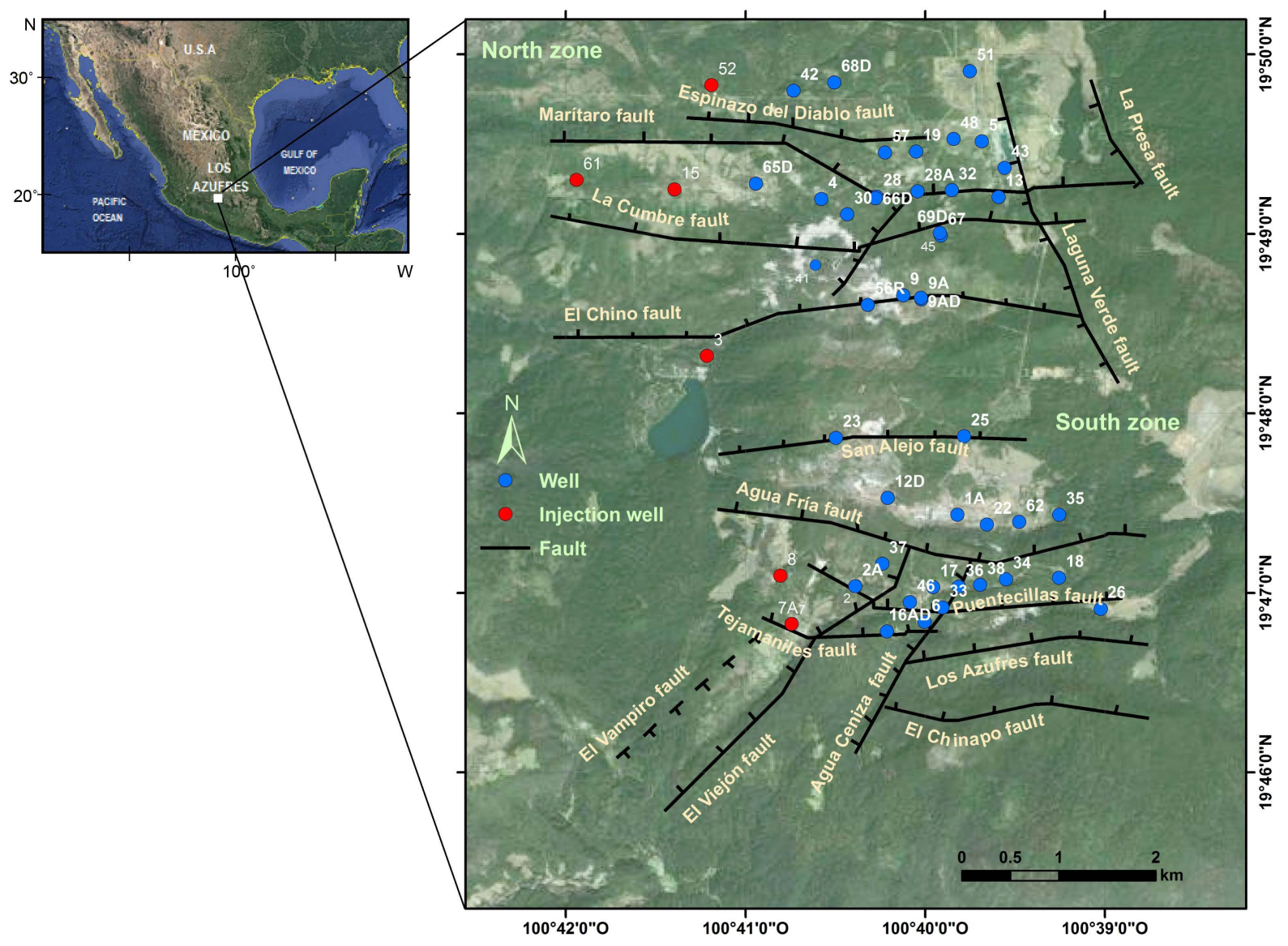

Figure 1. Location of the Los Azufres geothermal field and locations of wells. 
occurring because of exploitation, a method based on the analysis of the following patterns of behavior of production and geochemical indicators over time was used [4]:

1) Well mass flow-rates, well-bottom pressures, enthalpies, and temperatures. Well-bottom thermodynamic conditions (pressures, temperatures, enthalpies and quality of steam) were obtained through WELFLO simulator [5]. Input data consisted of wellhead production data and well geometry. WELFLO is a simulator of the mass and energy flows in the well that considers multiphase, one-dimension and steady state conditions and is suitable for vertical wells with variable diameter. Input data consists of geometry of the well, mass flow rates, and wellhead pressures and enthalpies.

2) In order to identify reservoir processes, a method based on the comparison of the total discharge enthalpy $\left(H_{\mathrm{TD}}\right)$ with other enthalpy estimations obtained through different approaches [6], was used. Thus, besides the reservoir temperatures given by well simulation, the following temperature estimations were obtained. For two-phase wells the cationic $\mathrm{Na} / \mathrm{K}$ [7] and the silica [8] geothermometers were estimated while for the steam wells, the FT-HSH2 gas geothermometer [9] [10] was used. From the cationic and silica reservoir temperatures, the enthalpies $\left(H_{\mathrm{Na} / \mathrm{K}}, H_{\mathrm{Si}}\right)$ were interpolated from the steam tables considering the occurrence of single saturated liquid in the reservoir. Simulation temperatures reflect actual temperatures at the entrance of wells, they usually compare fairly with gas and silica temperatures. Currently, cation geothermometers such as the $\mathrm{Na} / \mathrm{K}$ and $\mathrm{Na}-\mathrm{K}-$ Ca are considered "slow response" because they are based on the kinetics of the water-rock interactions which re-equilibrates relatively slowly and keep the memory of previously conditions. When considering "slow response" cation geothermometers one of the exceptions is the $\mathrm{K} / \mathrm{Mg}$ which re-equilibrates fast. In contrast, silica geothermometers are considered "fast response" because they are based on silica solubility, which depends on temperature. The general guidelines to interpret the enthalpies comparison tendencies are as follows.

3) Fraction of steam entering the well. This parameter can be obtained either from simulation of wells or can be estimated through gas equilibria methods [3] [9] [11]. In this work both methods provided similar results.

4) Chloride concentrations in total discharge and in separated water. The total discharge fluid is defined as that ascending from the well to the wellhead before steam separation due to de-pressurization. To calculate the total discharge concentrations of solutes, first, the steam removed $(y)$ during separation is obtained through an enthalpy $(H)$ balance, according to:

$$
H_{\mathrm{TD}}=y \cdot H_{\mathrm{S}, \mathrm{ST}}+(1-y) \cdot H_{\mathrm{L}, \mathrm{ST}}
$$

where $y$ is the steam fraction and subscripts TD, S, Land ST stand for total discharge, steam, liquid and separation temperature. From (1):

$$
y=\left(H_{\mathrm{TD}}-H_{\mathrm{L}, \mathrm{ST}}\right) /\left(H_{\mathrm{S}, \mathrm{ST}}-H_{\mathrm{L}, \mathrm{ST}}\right)
$$

Subsequently the total discharge $\mathrm{Cl}$ (as well as any other chemical species) concentration is obtained through a mass balance:

$$
\mathrm{Cl}_{\mathrm{TD}}=y \cdot \mathrm{Cl}_{\mathrm{S}, \mathrm{ST}}+(1-y) \cdot \mathrm{Cl}_{\mathrm{L}, \mathrm{ST}}
$$

5) Total discharge and reservoir $\mathrm{CO}_{2}$ concentrations. These concentrations were obtained through the SCEXVAP program [3] [12] with steam data as input.

6) Reservoir volumetric liquid saturation $\left(S_{\mathrm{L}}\right)$. This parameter is closely related to the production of the wells and was estimated according to the following expression [13]:

$$
S_{\mathrm{L}}=(1-y) \cdot V_{\mathrm{L}} /\left\{(1-y) \cdot V_{\mathrm{L}}+y \cdot V_{\mathrm{V}}\right\}
$$

where $V_{\mathrm{L}}$ and $V_{\mathrm{V}}$ are the specific volumes of liquid and steam at reservoir temperature respectively; $y$ is the fraction of steam entering the well.

7) $\delta^{18} \mathrm{O}$ and $\delta \mathrm{D}$ composition of total discharge fluids. This composition is calculated by using equations 2 and 3 and considering the partition coefficients, which depend on temperature, for every separation step that had occurred previous to sample collection [14].

Chemical, isotopic and production monitoring data were provided by the Residencia Los Azufres, CFE. The study included 39 wells (Figure 1): Az-4, 5, 9, 9A, 9AD, 13, 19, 28, 28A, 30, 32, 41, 43, 45, 48, 51, 56R, 65D, 66D, 67, and 69D from the north and Az-1A, 2A, 6, 16AD, 17, 18, 22, 23, 25, 26, 33, 34, 35, 36, 37, 38, 46, and 62 from the south zone of the field. 


\section{Fluid Production/Injection}

Fluid production and injection rates have varied depending on the operation of the generating units over time. Figure 2 shows the production and injection data as a function of time for the field. Fluid extraction started in 1978 (Figure 2) and by December 2011 an amount of 441,744,661 tons of fluids were produced. Of these, 254,376,326 tons (57.6\%) were from the south, and 187,368,335 tons (42.4\%) from the north. Between 1982 and 2011, an amount of 132,016,271 tons (30\%) of produced fluids had been re-injected to the reservoir. Production increased in the south zone in 1987, when the $50 \mathrm{MW}$ power plant came on line [4]. In 2003, fluid production in the north zone increased due to installation of the $100 \mathrm{MW}$ eadditional capacity.

\section{Results}

The results obtained allowed identification of the main processes that have occurred and are occurring in different zones of the Los Azufres reservoir. Two main processes were identified as follows. 1) Production of reinjection returns. According to the type of fluid arriving to the well, two sub-processes can occur: a) wells that receive liquid and steam from reinjection, and b) wells that receive steam originated from the boiling of reinjection fluids and/or wells that receive condensed steam originated from boiling of reinjection fluids. 2) Boiling. Depending on the boiling rate (increasing or decreasing rates), boiling can be classified as: a) boiling with steam gain or increasing boiling rate and b) boiling with steam loss.

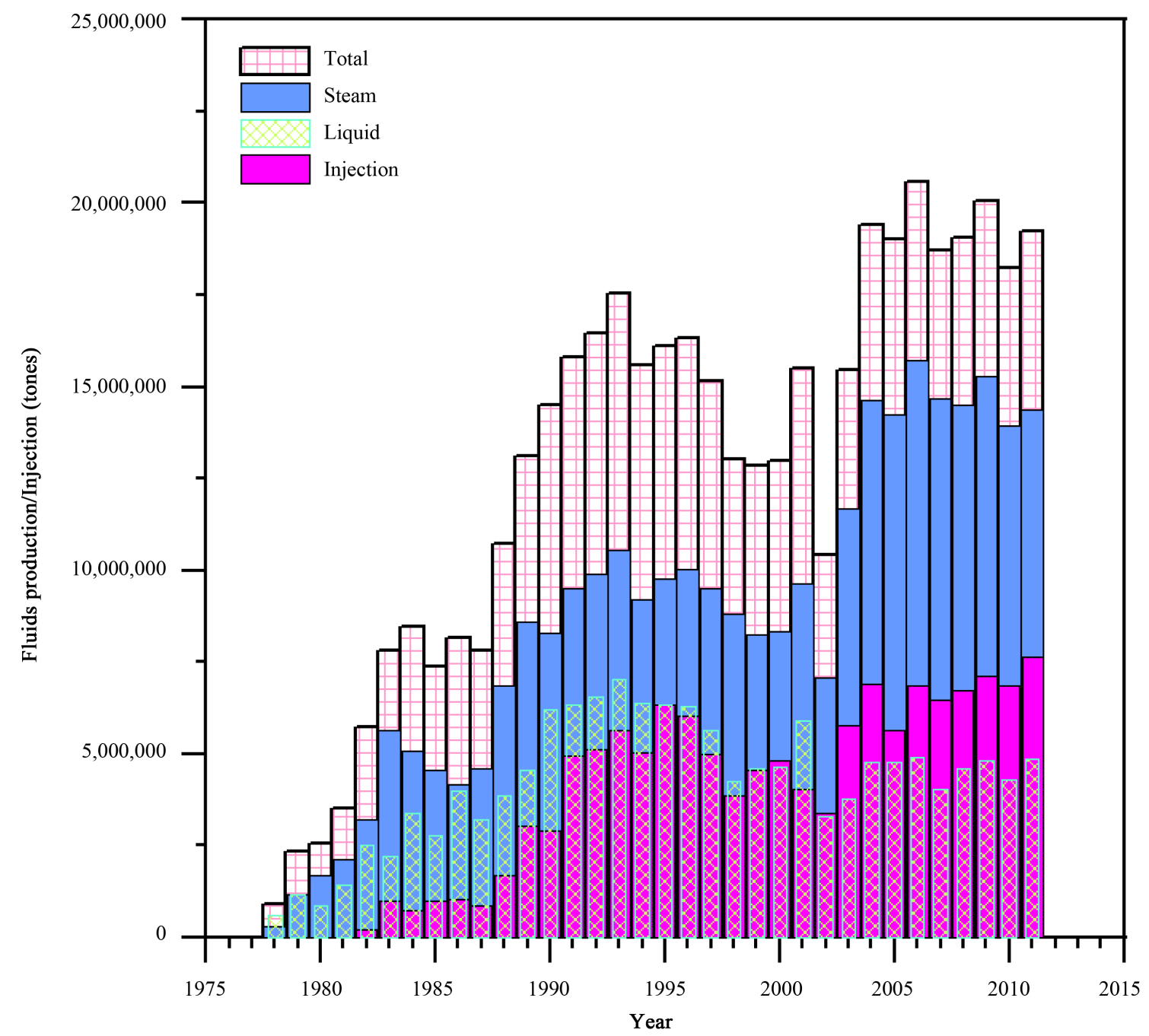

Figure 2. Production and reinjection fluids in Los Azufres geothermal field. 


\subsection{Reservoir Processes}

\subsubsection{Production of Reinjection Returns (IR's)}

In order to illustrate this process, the well Az-33 was selected. This well is $683 \mathrm{~m}$ deep, with $81 \mathrm{~m}$ of slotted liner that receives (IR's) in liquid phase. In Figure 3 time series of mass flow rates, well bottom pressure, well bottom enthalpy, chlorides, wellhead pressure, comparison of total discharge enthalpy and enthalpy estimations by geothermometers, $\mathrm{CO}_{2}$, and reservoir liquid saturation for the well Az-33 are given. As seen in Figure 3(A) large variations in mass flow rates between 1988 and 2003 are seen, which are due mostly to variations in water production. Since 2004 the production of well showed a decreasing trend over time while up to middle 2007 the well became dried due to the shutting out of one of the injectors, the well Az-7R. Since then, the well produced small amounts of liquid and the decreasing tendency changed to a more stable production up to 2011 and even an increase in production was noticed during 2008. However it appears that during 2009 and 2010 the liquid production vanished; (B) as in the cases where the wells receive IR's, the well bottom pressure changes abruptly due to the recharge entry, since 2004 the pressure decreases with the same tendency found for mass flow rates and $(\mathrm{C})$ the well bottom enthalpy increases and decreases depending on the entry of liquid recharge; (D) the total discharge chlorides increase and $(\mathrm{G})$ the total discharge $\mathrm{CO}_{2}$ increases. The pattern for the enthalpies comparison in (F) shows mixing of equilibrated liquid with steam produced by boiling away the well, it is also noticed that between 1996 to 2003 the $\mathrm{Na} / \mathrm{K}$ enthalpy is slightly lower than the silica enthalpy which is characteristic of the entry of reinjection water. In Figure 4(A) it is seen that the well Az-33 has received reinjection fluids some years through the increase in chlorides and, as the injection rates are not constant over time, the behavior of the well shows intermittent changes in Figures 3(A)-(H) and Figure 4(A) and Figure 4(B). In Figure 4(A) the enthalpy-chloride data of well Az-33 are found to the right hand side of the characteristic boiling line which constitutes the reference for the field [4]. This is due to the chloride enrichment of the fluids discharged because of production of reinjection returns. Chloride and other solutes are highly concentrated in injection fluids since they are evaporated at ambient conditions before injection. The well Az-33 as other wells, shows important
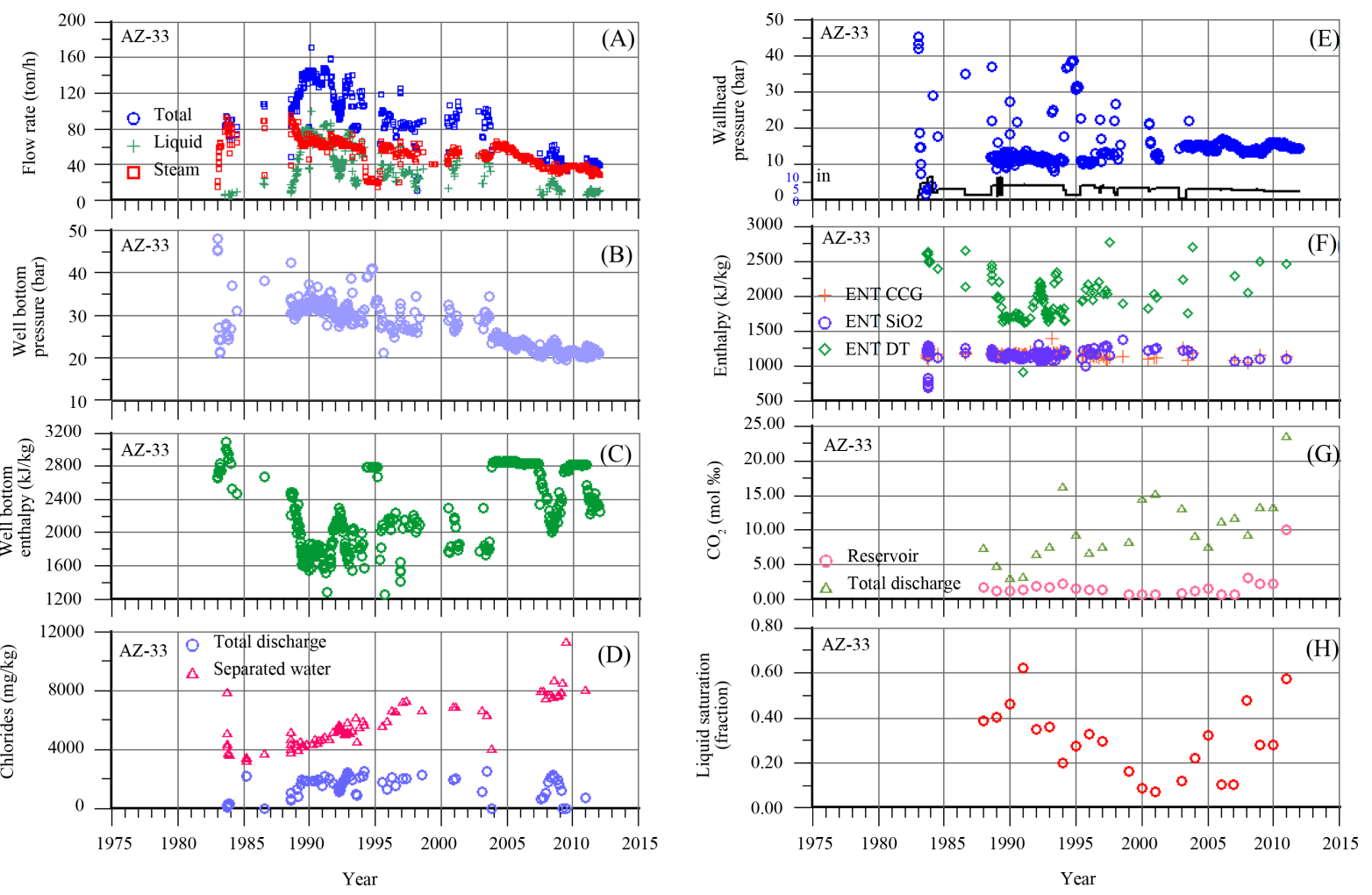

Figure 3. Time series of (A) mass flow rates, (B) well bottom pressure, (C) well bottom enthalpy, (D) chlorides, (E) wellhead pressure, (F) comparison of total discharge enthalpy and enthalpy estimations by geothermometers, $(\mathrm{G}) \mathrm{CO}_{2}$, and (H) reservoir liquid saturation of well Az-33. 


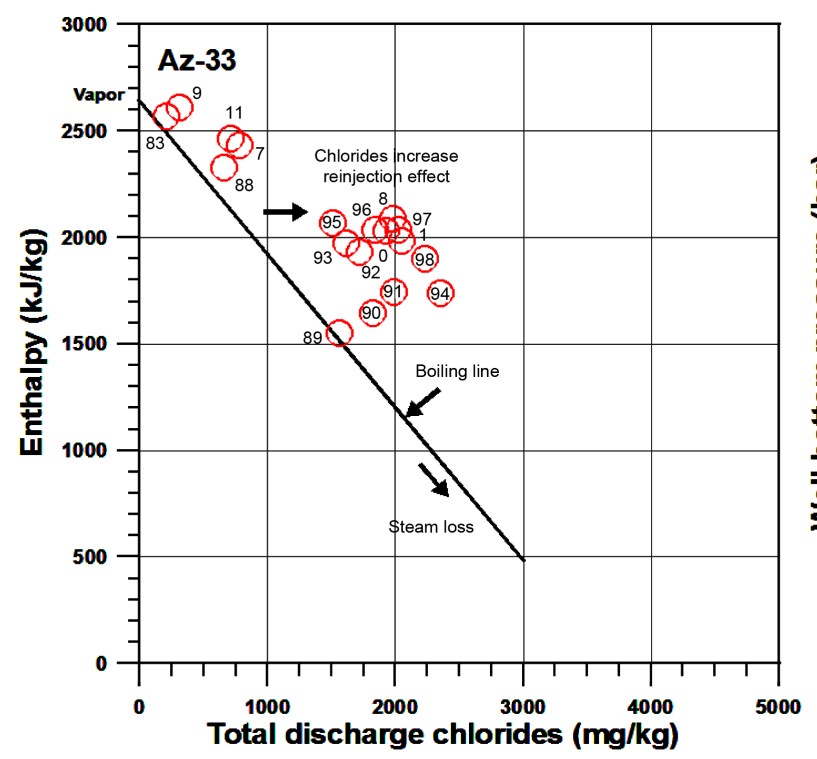

(A)

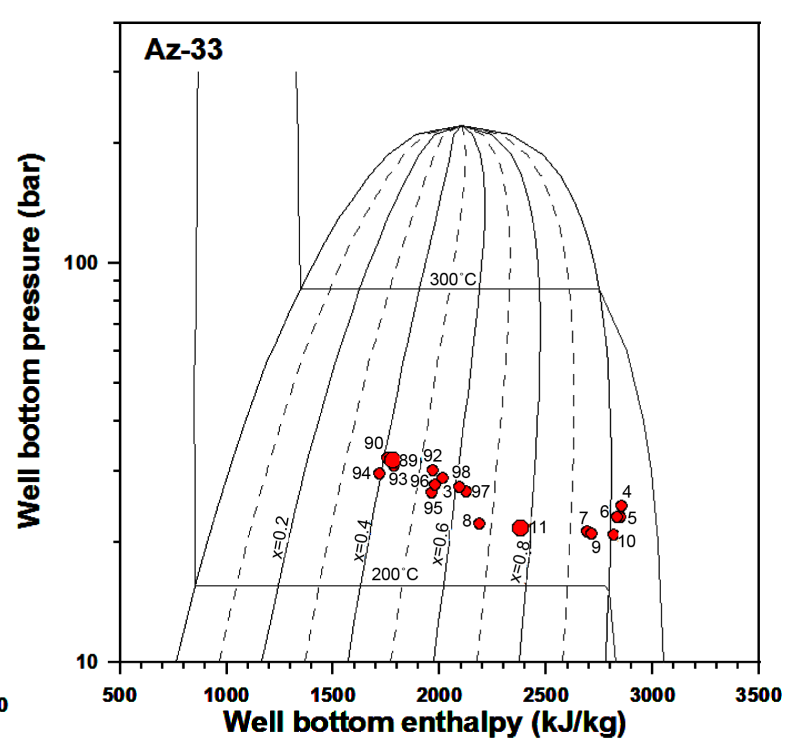

(B)

Figure 4. (A) Enthalpy versus chlorides and (B) well bottom pressure versus well bottom enthalpy for well Az-33.

recovery in liquid saturation since 2004-2005 (Figure 3(H)), this can be related to the operation of the injection well Az-7AR which replaced the original injection well Az-7R. As was mentioned, the well Az-33 produced two-phase fluids but became steam producer when the injector well Az-7R was closed in 2003. The well Az-33 started producing liquid intermittently in 2007 (Figure 3(A)). Results from tracer tests [15] indicate that part of the fluids injected in well Az-8R are recovered as both liquid and steam in well Az-33. However the well Az-33 develops a moderate and sometimes important boiling process depending on reinjection rates, which can be seen in Figure 3(C) and Figure 3(F) through the enthalpy variations.

The production of injection returns is shown only by some wells of the south zone such as Az-1A, 2, 2A, 16D, 36 and 46, where injection plays an important role. From these, the wells Az-36 and 46 became dried when the well Az-7R was shut off. The well Az-7R was replaced by the well 7AR, which seemed not to provide enough recharge to the wells Az-33, 36 and 46 to change their flow regime to two-phase. In wells that receive reinjection returns in liquid phase, chlorides concentrations in separated water are as high as $5500-8000$ (mg/kg) contrasting with initial concentrations which were recorded as between 2500 - 4000 (mg/kg).

The production of steam from the boiling of reinjection fluids and sometimes condensed steam from the boiling of injection fluids, was also identified to occur in some wells of the field. When injection fluids consist of recycled produced fluids, the effects of reinjection in two-phase production wells are routinely noticed on the salts increase in the discharged liquid [4] [14] [16]-[18] as was illustrated for well Az-33. However, injected fluids in contact with reservoir rocks are heated and eventually evaporated by boiling, then either as steam or as condensed steam they flow to the production zones of wells. These types of reinjection returns could not be recognized in production wells by the increase in the salinity of the liquid discharged, since condensed steam is both salts and isotope-depleted. Thus, in two-phase wells that produce evaporated or condensed reinjection returns, a decrease in salinity is observed. In order to recognize the presence of injection returns consisting of steam or condensed steam gas and isotope data should be analyzed. Basically, when production of steam from reinjection occurs, the following characteristics are seen in the produced fluids: 1) $\mathrm{N}_{2} / \mathrm{Ar}$ molar ratios lower than that for air saturated water (38); 2) low gas and $\mathrm{CO}_{2}(<5 \%)$ concentrations and 3$)$ relative $\delta \mathrm{D}$ and $\delta^{18} \mathrm{O}$ depletion.

In the south zone the production of evaporated or condensed reinjection returns is seenin wells Az-1A, 23 and 25 while in the wells Az-22, 35 and 62, the production is intermittent depending on reinjection rates. In contrast, mainly after 2005, in the north zone a number of wells produce steam or condensed steam from the boiling of reinjection fluids: Az-4, 9, 19, 28, 28A, 45, 51, 57, 66D, 67 and 69D; while wells Az-5, 13, 32, 42 and 48 produce such returns in an intermittent way. In Figure 5 the $\mathrm{N}_{2}$-He-Ar ternary diagrams for (A) well Az-9 


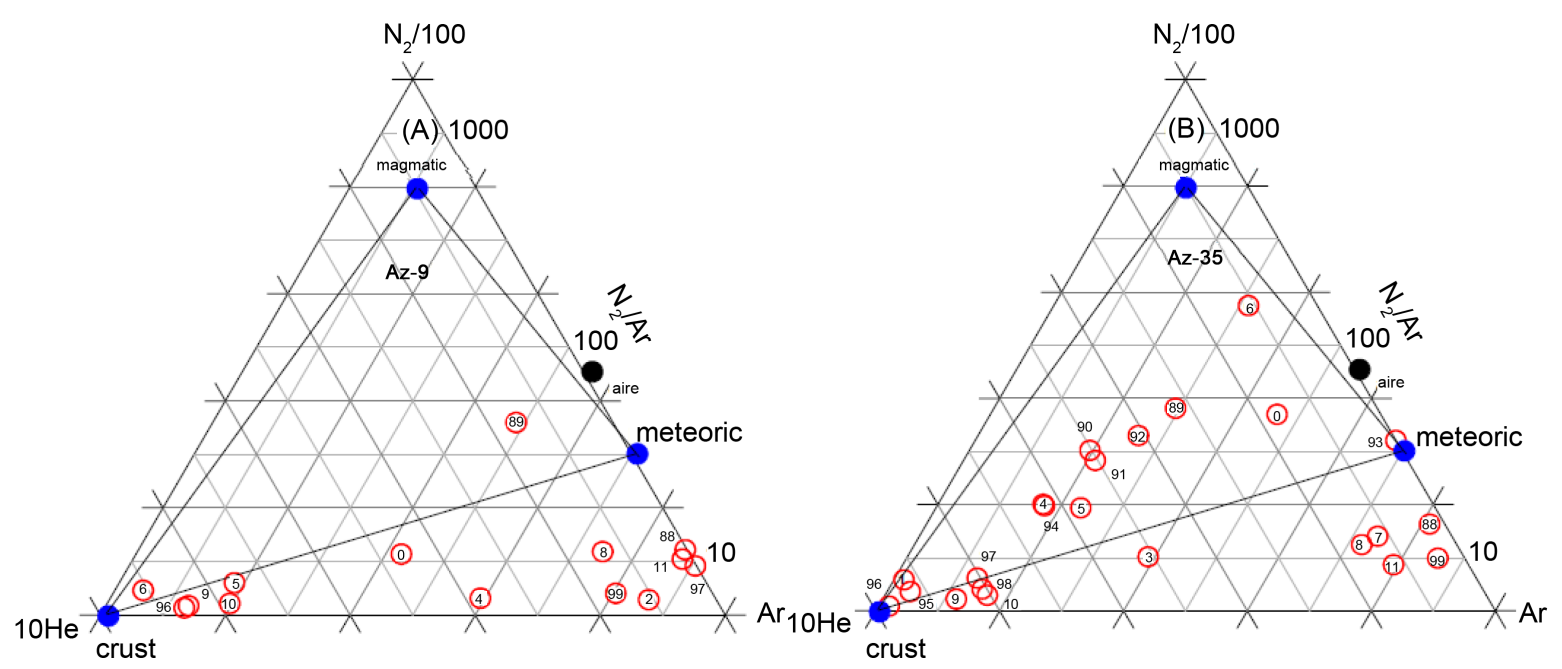

Figure 5. The $\mathrm{N}_{2}$-He-Ar ternary diagrams for (A) well Az-9 (two-phase) and (B) Az-35 (steam) [21].

(two-phase) and (B) Az-35 (steam) are given, as it is seen both wells receive evaporated or condensed injection when data plot below the He corner-meteoric line. Well Az-9 produces mostly evaporated or condensed reinjection fluids (Figure 5(A)), which explains the production of slightly lighter fluids in 2010 in Figure 6(A) [18] $\left(\delta^{18} \mathrm{O}\right.$ of $-3.5 \%$ o, $\delta \mathrm{D}$ of $-63.5 \%$ ) considering the isotopic composition taken as reference $\left(\delta^{18} \mathrm{O}\right.$ of $-2.4 \%$ o, $\delta \mathrm{D}$ of $-61 \%$ ) [3]. The well Az-28 has also become isotopically lighter regarding its reference composition $\left(\delta^{18} \mathrm{O}\right.$ of $-2.51 \%$, $\delta \mathrm{D}$ of $-61.8 \%$ ) because of the production of condensed reinjection fluids. This is seen in Figure 6(A) where 2010 point is very close to the lighter end of the fitting line [19]. In contrast, according to Figure 5(B) the steam well Az-35 (south zone) in 2010 and 2011, as intermittently occurs, received steam from reinjection. This causes the deuterium enrichment of well Az-35 regarding the fitting line in Figure 6(B), considering that deuterium partitions preferably in steam at temperatures above $220^{\circ} \mathrm{C}$ [20]. In Figure 6(B) the isotopic compositions of two-phase wells Az-1A, 23 and 25, which produce condensed reinjection fluids, are the more depleted in the south zone because of this effect.

\subsubsection{Boiling}

The boiling processes in wells are a natural response to exploitation, due to pressure drops induced by fluids extraction. Depending on rates of boiling (increase/decrease) in wells this process has two sub-processes as follows. 1) Boiling with steam gain (increasing boiling rate) and 2) boiling with steam loss (decreasing boiling rate).

The boiling with steam gain process was noticed in some wells of Los Azufres such as Az-5, 13 and 28 from the north zone and Az-18 and 26 from the south zone, among others [4] [21]. From these, the Az-5, 13 and 18 became dried after being first two-phase producers. In order to illustrate the case of boiling with gaining steam the well Az-28 was selected. In Figure 7 the behavior of (A) production mass flow rates, (B) well bottom pressure and (C) enthalpy, (D) $\mathrm{Cl}$, (E) wellhead pressure, (F) enthalpies comparison patterns (G) $\mathrm{CO}_{2}$ and $(\mathrm{H})$ volumetric liquid saturation over time, is shown. As seen, the liquid production in well Az-28 increased from 1991 to 1993 but after 1995 it decreased to minimum values at the end of 2003. The well became dried from 2006 to 2010 and then started producing liquid again. The steam production showed an increasing tendency from 1991 to the end of 2004, after that and up to 2011 the steam production is rather stable with a slight declining tendency. These variations in production sometimes are due to changes in operating conditions controlled by the orifice plate (E). On average, the pressure declining was estimated as $0.7 \mathrm{bar} / \mathrm{year}$ and the enthalpy increased 38.7 $(\mathrm{kJ} / \mathrm{kg}) /$ year; $\mathrm{Cl}$ in total discharge decreased $58(\mathrm{mg} / \mathrm{kg}) /$ year while $\mathrm{CO}_{2}$ increased $0.03(\% \mathrm{~mol}) /$ year. The enthalpies comparison patterns (F) indicates the mixture of equilibrated liquid with steam formed by boiling far from the well which is due to the development of an important boiling process in this zone of the field. This is shown in Figure 8(B) through the evolution of the thermodynamic conditions that shows production of saturated or even superheated steam during 2006-2010. The 2011 data on this diagram shows that enthalpy has decreased and the two-phase mixture entering the well has a steam fraction of 0.75 . In Figure 8(A) it is seen that this well 


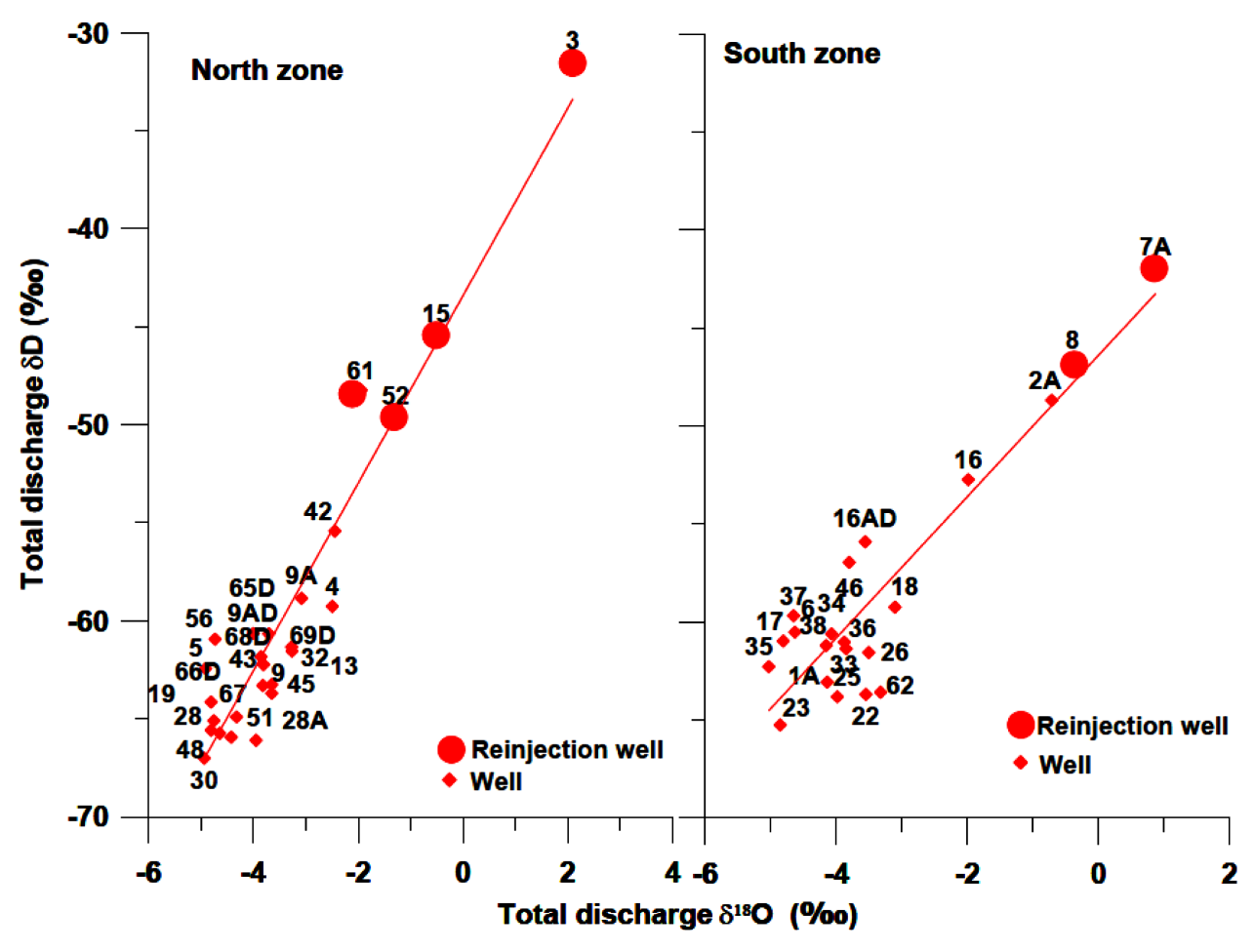

(A)

(B)

Figure 6. $\delta$ D versus $\delta^{18} \mathrm{O}$ compositions of (A) North zone and (B) South zone wells according to 2010 data [18].
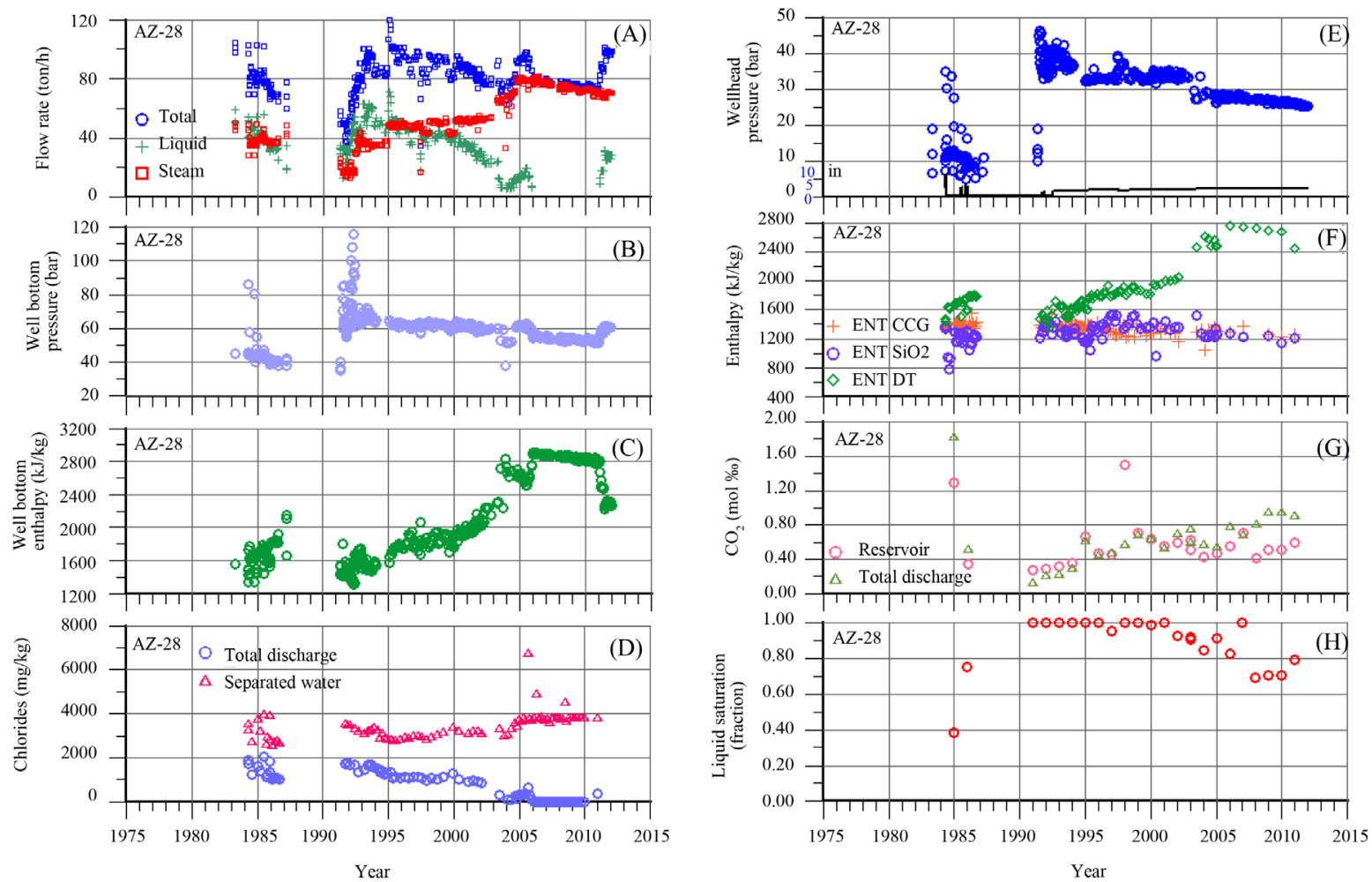

Figure 7. Time series of (A) mass flow rates, (B) well bottom pressure, (C) well bottom enthalpy, (D) chlorides, (E) wellhead pressure, $(\mathrm{F})$ comparison of total discharge enthalpy and enthalpy estimations by geothermometers, $(\mathrm{G}) \mathrm{CO}_{2}$, and (H) reservoir liquid saturation of well Az-28. 


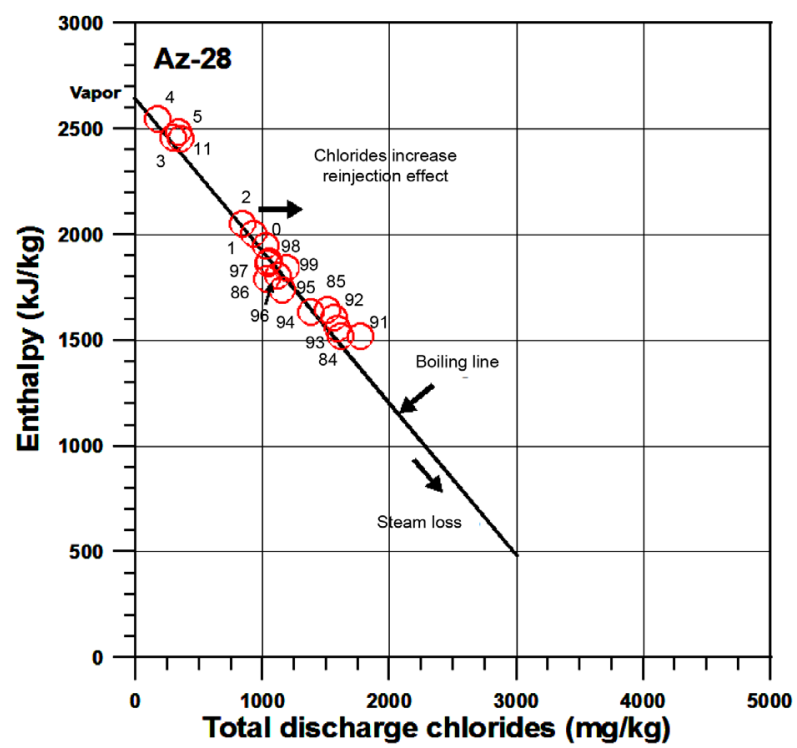

(A)

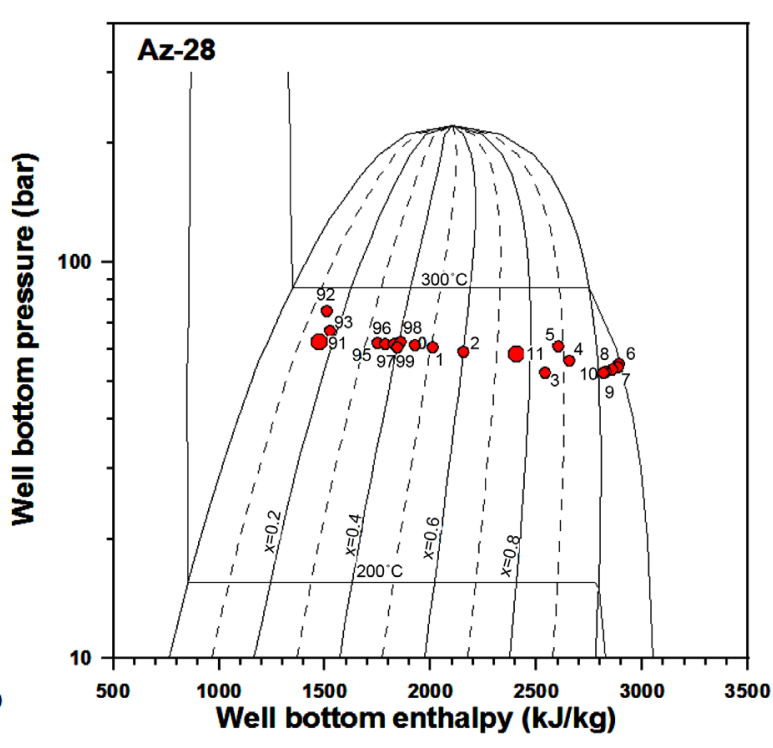

(B)

Figure 8. (A) Enthalpy versus chlorides and (B) well bottom pressure versus well bottom enthalpy for well Az-28.

plots on the characteristic boiling line of the field and no $\mathrm{Cl}$ increases are seen related to production of production of returns of reinjection consisting of liquid. However the $\mathrm{N}_{2} / \mathrm{Ar}$ ratio is lower than that for air-saturated water and indicates the production of de-gasified fluid while a tracer test [22] concluded connectivity between well Az-28 and the reinjection well Az-15R.

The boiling with steam loss process consists in the decreasing of boiling rate in a well and was identified to occur in very few wells of the field, such as Az-23 and 28A [21] and for short periods of time, in some other wells. Considering the well Az-23, in Figure 9(A) it is seen a decreasing trend for the enthalpy between 2007 and 2010, just above the boiling line, while chloride increases. Also in Figure 9(B) the well Az-23 shows that the well bottom enthalpy decreased between 2006 and 2010. In Figure 10, time series of (A) mass flow rates produced; (B) the total discharge enthalpy and estimated silica and $\mathrm{Na} / \mathrm{K}$ enthalpies; (C) $\mathrm{CO}_{2}$ and (D) liquid saturation at reservoir for well Az-23 are given. As seen in Figure 10(A) the mass flow rate shows variations with a decreasing trend since 2008 up to 2010 while it stabilizes in 2011. The patterns of enthalpies comparison provides $\mathrm{H}_{\mathrm{TD}}=\mathrm{H}_{\mathrm{Na} / \mathrm{K}}>\mathrm{H}_{\mathrm{Si}}$ indicating the mixing (close to the well) of equilibrated liquid with less-temperature more diluted water probably related to the entry of condensed reinjection returns. This process is the responsible of the decreasing enthalpy trend. As the fluid entering the well comes from reinjection it is $\mathrm{CO}_{2}$-depleted regarding reservoir fluids, thus $\mathrm{CO}_{2}$ shows a decreasing trend over time in Figure 10(C). Well Az-23 has a very high liquid saturation as seen in Figure 10(D).

\subsection{5-2011 Reservoir Temperatures}

The occurrence of the described reservoir exploitation-related processes has changed the distributions of temperature through time as follows. In Figure 11 the temperature distributions of the Los Azufres reservoir for 2005 and 2011are given. The more important changes include temperature variations in the north zone, where with respect to 2005 , the $300^{\circ} \mathrm{C}$ contour is located toward the east. In 2011 the temperature iso-contours are aligned in an approximately N-S direction in the center of the north zone with a decreasing trend toward the west, where injection wells are located. In 2011 the $290^{\circ} \mathrm{C}$ contour is lying along both zones of the field while minimum temperatures are located in the west of the south zone where injection wells are located.

\section{Conclusions}

The analysis of chemical and production data for the Los Azufres geothermal field allowed the main reservoir processes related to exploitation to be identified. According to the results, after 27 years of commercial exploitation 


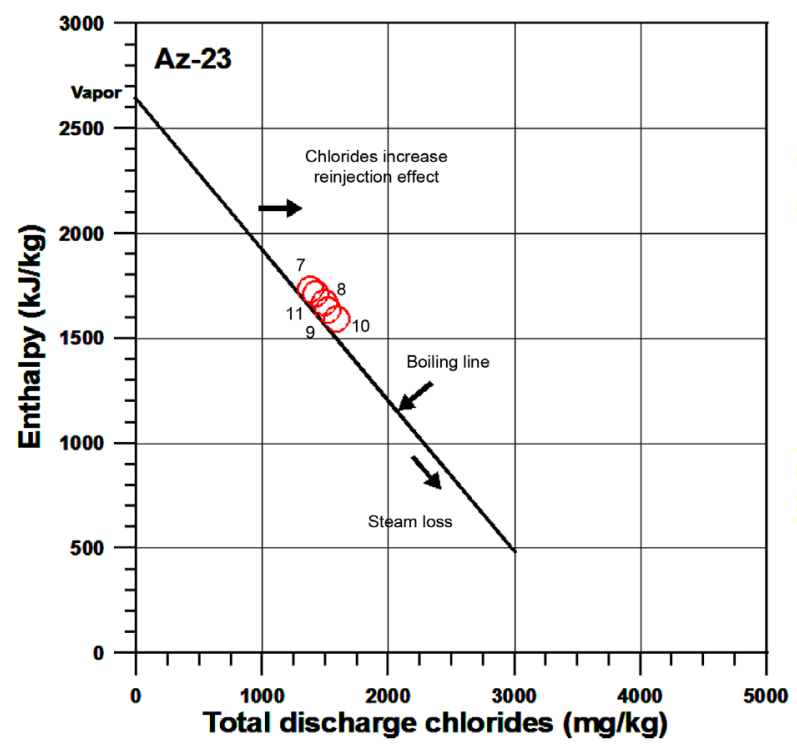

(A)

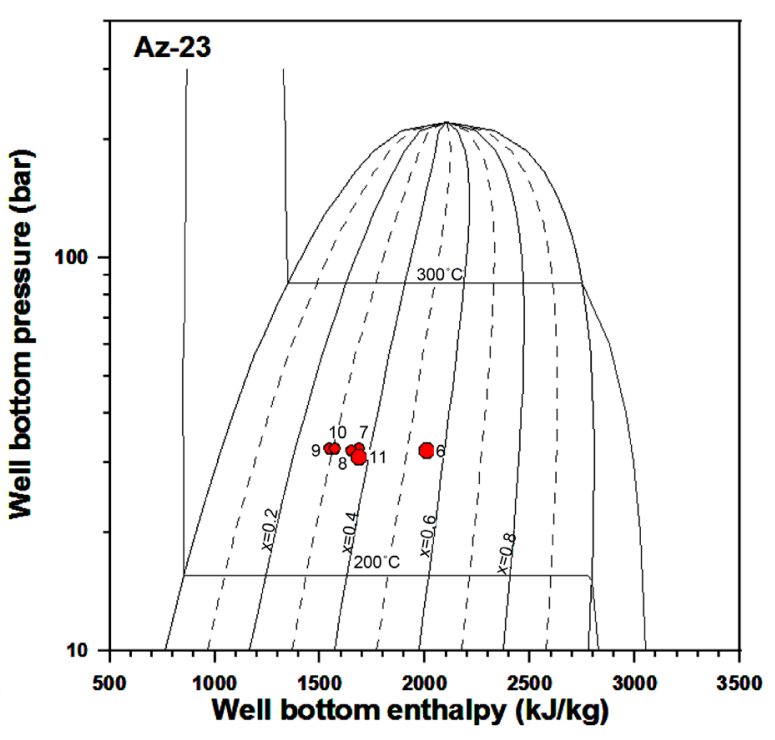

(B)

Figure 9. (A) Enthalpy versus chlorides and (B) well bottom pressure versus well bottom enthalpy for well Az-23.
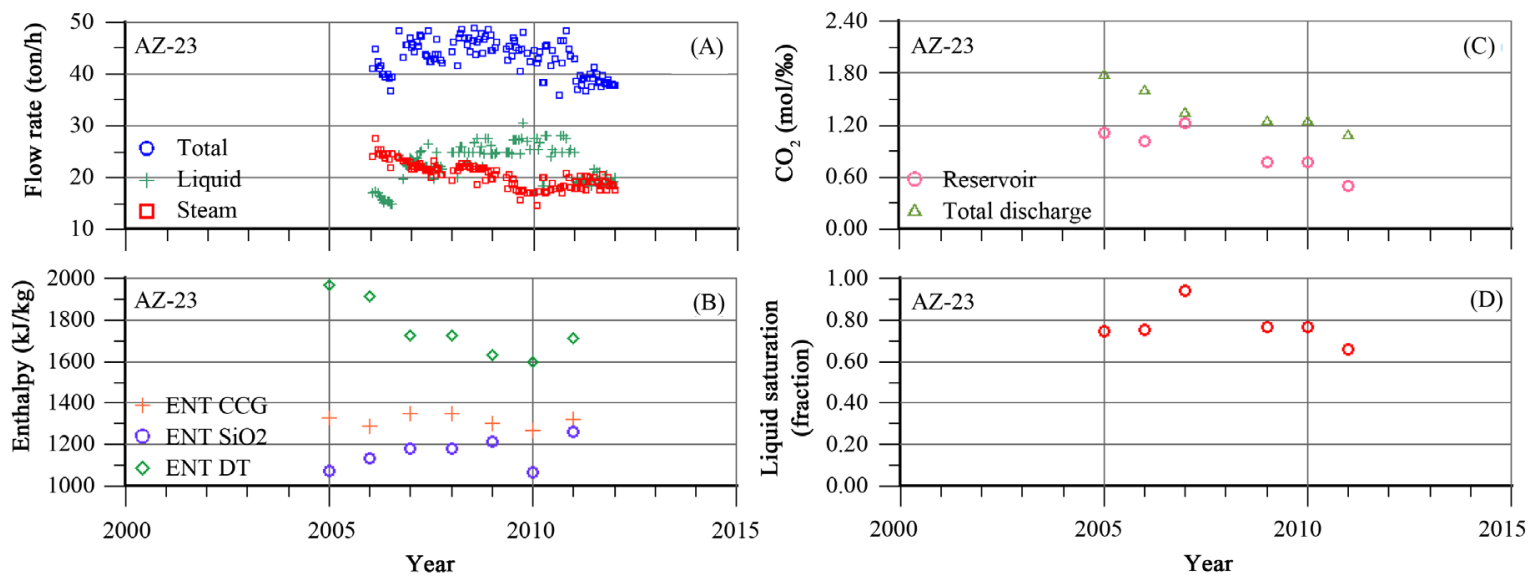

Figure 10. Time series of (A) mass flow rates, (B) comparison of total discharge enthalpy and enthalpy estimations by geothermometers, (C) $\mathrm{CO}_{2}$, and (D) reservoir liquid saturation of well Az-23.

of the field, very moderate declining in production parameters was estimated which is due to an efficient artificial and natural recharge to the reservoir. The extraction and reinjection of fluids from and to the reservoir have induced the occurrence of mainly two physical processes: 1) the production of returns from reinjection and 2) boiling. The more important process was the production of reinjection returns either as liquid or steam, and the production of steam and sometimes condensed steam from boiling of injection fluids. Then, for the first time it is reported that when returns from injection consist of condensed steam, salinity decreases in two-phase wells and isotopic compositions become relatively-depleted. In order to recognize the production of such reinjection returns, the analysis of gas data in particular the $\mathrm{N}_{2} / \mathrm{Ar}$ molar ratio is necessary. The other process induced by exploitation was boiling, which can take place either with gaining steam, in which rates of boiling over time tend to increase, or with steam loss, in which the boiling rates over time tend to decrease.

It is recommended to continue the monitoring of geochemical and production data to follow the evolution of the reservoir due to exploitation and support decisions focused on extending the resource lifetime.

\section{Acknowledgements}

Authors acknowledge the authorities of Gerencia de Proyectos Geotermoeléctricos (Comisión Federal de 

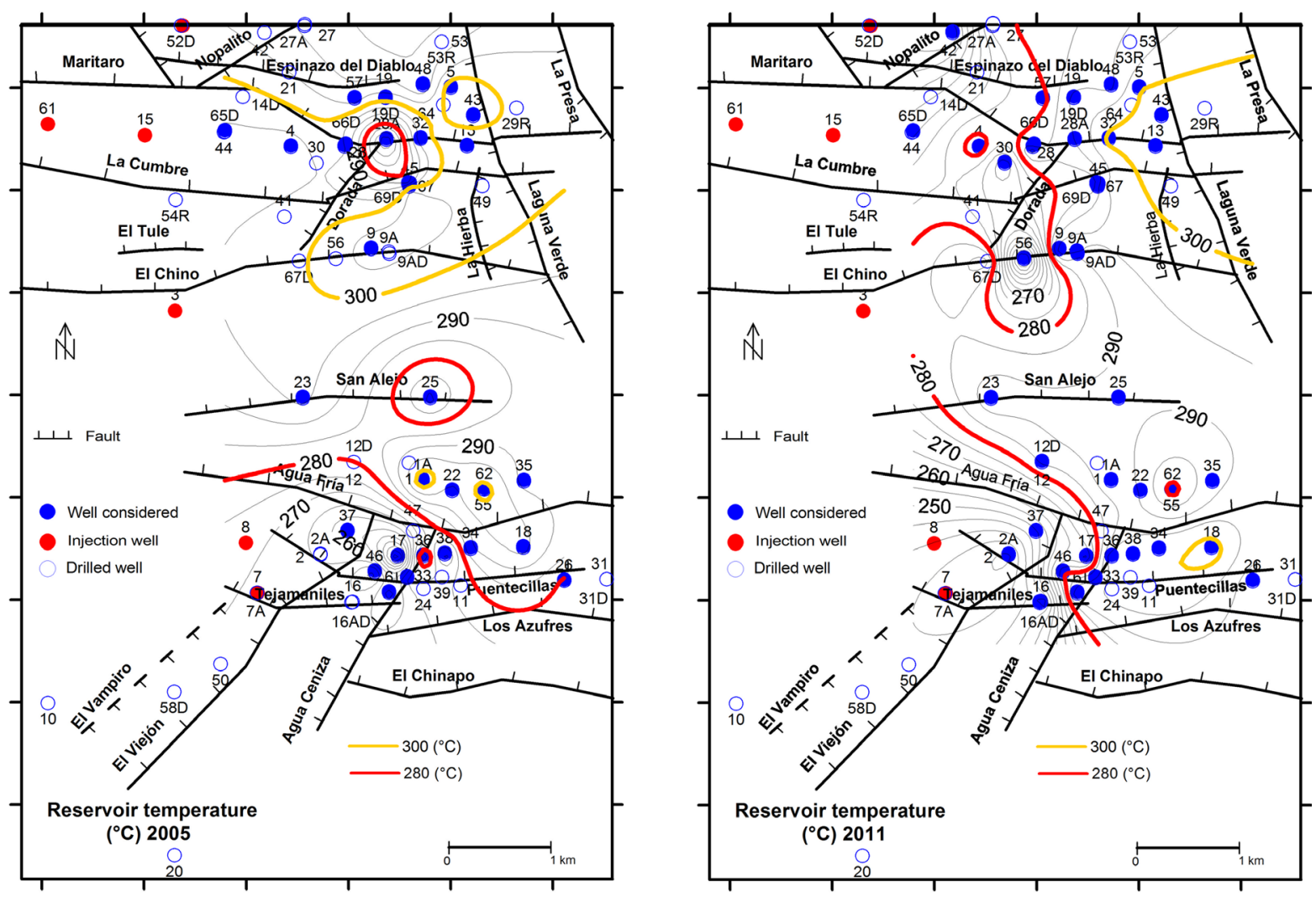

Figure 11. 2005 and 2011 distributions of reservoir temperature in the Los Azufres geothermal field [21].

Electricidad, CFE) for authorizing this publication. Recognition is given to the technical staff of the Residencia Los Azufres (CFE) who provided support for this work.

\section{References}

[1] Gutiérrez-Negrín, L. (2015) Mexico: Update of the Country Update, and IRENA’s Remap. IGA News, 100, 17-19.

[2] Iglesias, E.R., Arellano, V.M., Garfias, A., Miranda, C. and Aragón, A. (1985) A One-Dimensional Vertical Model of the Los Azufres, México, Geothermal Reservoir in its Natural State. Geothermal Resources Council Transactions, 9, 331-336.

[3] Nieva, D., Verma, M., Santoyo, E., Barragán, R.M., Portugal, E., Ortíz, J. and Quijano, L. (1987) Chemical and Isotopic Evidence of Steam Upflow and Partial Condensation in Los Azufres Reservoir. Proceedings of 12th Workshop on Geothermal Reservoir Engineering Stanford University, Stanford, CA, 20-22 January 1987, 253-259.

[4] Arellano, V.M., Torres, M.A. and Barragán, R.M. (2005) Thermodynamic Evolution of the Los Azufres, Mexico, Geothermal Reservoir from 1982 to 2002. Geothermics, 34, 592-616. http://dx.doi.org/10.1016/j.geothermics.2005.06.002

[5] Goyal, K.P., Miller, C.W. and Lippmann, M.J. (1980) Effect of Measured Wellhead Parameters and Well Scaling on the Computed Downhole Conditions in Cerro Prieto Wells. Proceedings of 6th Workshop on Geothermal Reservoir Engineering Stanford University, Stanford, CA, 16-18 December 1980, 130-138.

[6] Truesdell, A.H, Lippmann, M., Quijano, J.L. and D’Amore, F. (1995) Chemical and Physical Indicators of Reservoir Processes in Exploited High-Temperature, Liquid-Dominated Geothermal Fields. Proceedings of World Geothermal Congress, Florence, Italy, 18-31 May 1995, 1933-1938.

[7] Nieva, D. and Nieva, R. (1987) Developments in Geothermal Energy in Mexico-Part Twelve: A Cationic Geothermometer for Prospecting of Geothermal Resources. Heat Recovery Systems \& CHP, 7, 243-258. http://dx.doi.org/10.1016/0890-4332(87)90138-4

[8] Fournier, R.O. and Potter II, R.W. (1982) A Revised and Expanded Silica (quartz) Geothermometer. Geothermal Resources Council Bulletin, 11, 3-12. 
[9] Siega, F.L., Salonga, N.D. and D’Amore, F. (1999) Gas Equilibria Controlling H2S in Different Philippine Geothermal Fields. Proceedings of 20th Annual PNOC-EDC Geothermal Conference, Manila, Philippines, March 10-12, 1999, 2935.

[10] Barragán, R.M., Arellano, V.M., Aragón, A., Torres, R., Reyes, N., López, S. and Patiño, A. (2013) Estudio Isotópico de Fluidos de Pozos Productores y de Reinyección del Campo Geotérmico Los Azufres, Mich. 2013. Final Report, $I I E / 11 / 14154 / I 01 / F$, Instituto de Investigaciones Eléctricas for the Comisión Federal de Electricidad, Cuernavaca, Morelos, México. (In Spanish)

[11] Arellano, V.M., Torres, M.A., Barragán, R.M., Sandoval, F. and Lozada, R. (2003) Chemical, Isotopic and Production Well Data Analysis for the Los Azufres (Mexico) Geothermal Field. Geothermal Resources Council Transactions, 27, 275-279.

[12] Barragán, R.M., Arellano, V.M., Rodríguez, M.H., Pérez, A. and Segovia, N. (2010) Gas Geochemistry Related to Wellhead Production Data to Investigate Physical Reservoir Phenomena in Geothermal Reservoirs: Application at Cerro Prieto IV (Mexico). Geofluids, 10, 511-524. http://dx.doi.org/10.1111/j.1468-8123.2010.00319.x

[13] D’Amore, F. and Truesdell, A.H. (1995) Correlation between Liquid Saturation and Physical Phenomena in VaporDominated Geothermal Reservoir. Proceedings of the World Geothermal Congress, Florence, 18-31 May 1995, 19271932.

[14] Barragán, R.M., Arellano, V.M., Portugal, E. and Sandoval, F. (2005) Isotopic $\left(\delta^{18} \mathrm{O}, \delta \mathrm{D}\right)$ Patterns in Los Azufres (Mexico) Geothermal Fluids Related to Reservoir Exploitation. Geothermics, 34, 527-547. http://dx.doi.org/10.1016/j.geothermics.2004.12.006

[15] Iglesias, E.R., Flores-Armenta, M., Torres, R.J., Ramírez-Montes, M., Reyes-Piccaso, N. and Reyes-Delgado, L. (2011) Estudio con Trazadores de Líquido y Vapor en el Área Tejamaniles del Campo Geotérmico de Los Azufres, Mich. Geotermia Revista Mexicana de Geoenergía, 24, 38-41. (In Spanish)

[16] Arnórsson, S. (2000) Injection of Waste Geothermal Fluids: Chemical Aspects. Proceedings of the World Geothermal Congress, Kyushu-Tohoku, 28 May-10 June 2000, 3021-3024.

[17] Arnórsson, S. and D’Amore, F. (2000) Monitoring of Reservoir Response to Production. In: Arnórsson, S., Ed., Isotopic and Chemical Techniques in Geothermal Exploration Development and Use: Sampling Methods, Data Handling, Interpretation, International Atomic Energy Agency, Vienna, 309-341.

[18] Barragán, R.M., Arellano, V.M., Aragón, A., Martínez, J.I., Mendoza, A. and Reyes, L. (2010) Geochemical Data Analysis of Los Azufres Geothermal Fluids (Mexico). In: Birkle, P. and Torres-Alvarado, I., Eds., Proceedings of the Water Rock Interaction, Taylor \& Francis Group, London, 137-140.

[19] Barragán, R.M., Arellano, V.M., Mendoza, A. and Reyes, L. (2011) Chemical and Isotopic $\left(\delta^{18} \mathrm{O}, \delta \mathrm{D}\right)$ Behavior of Los Azufres (Mexico) Geothermal Fluids Related to Injection as Indicated by 2010 Data. Geothermal Resources Council Transactions, 35, 603-608.

[20] Truesdell, A.H., Nathenson, M. and Rye, R.O. (1977) The Effects of Subsurface Boiling and Dilution on the Isotopic Compositions of Yellowstone Thermal Waters. Journal of Geophysical Research, 82, 3694-3704. http://dx.doi.org/10.1029/JB082i026p03694

[21] Arellano, V.M., Barragán, R.M., Ramírez, M., López, S., Paredes, A., Aragón, A., Casimiro, E. and Reyes, L. (2015) The Los Azufres (México) Geothermal Reservoir: Main Processes Related to Exploitation (2003-2011). Proceedings of the World Geothermal Congress, Melbourne, 19-25 April 2015, Paper 14028, 1-10.

[22] Iglesias, E.R., Flores-Armenta, M., Quijano, J., Torres, M., Torres, R.J. and Reyes-Piccaso, N. (2008) Estudio con trazadores de líquido y vapor en la zona Marítaro-La Cumbre del campo geotérmico de Los Azufres, Mich. Geotermia Revista Mexicana de Geoenergía, 21, 12-24. (In Spanish) 